\title{
A intolerância de sempre e a de hoje: uma leitura psicanalítica
}

\author{
The usual intolerance and present one: a psychoanalytic view \\ http://dx.doi.org/10.5007/2178-4582.2017v51n1p158
}

\author{
Pedro Luiz Ribeiro de Santi \\ Escola Superior de Propaganda e Marketing, São Paulo/SP, Brasil
}

\begin{abstract}
Neste artigo, analiso as raízes da intolerância de uma perspectiva psicanalítica e as formas que ela tem tomado em nossa vida política nos últimos anos. Em primeiro lugar, exponho uma concepção sobre a relação entre a intolerância e a formação do Eu para, então, compreender as mudanças sobre o que é ou não tolerável em diferentes contextos. Em seguida, passo a uma análise das condições psicossociais para a tolerância ao outro, desenvolvendo o argumento de que uma falha da intermediação simbólica é um fator importante nas formas contemporâneas da intolerância. Ante a esta falha, as relações com ideias e pessoas permanecem presas no imaginário e a capacidade de reflexão é inibida, como num fetiche. Concluo que é na instituição de uma intermediação simbólica entre o Eu e o Outro que pode haver uma condição de convivência mais tolerante.
\end{abstract}

Palavras-chave: intolerância; psicanálise; contemporaneidade.
In this article, I analyze the roots of intolerance from a psychoanalytic perspective, as well as the ways it has been taken in our politic life in the last years. At first, I expose a relation between intolerance and the Ego origin; in order to understand what changes in the measure of what is or isn't tolerable in distinct contexts. After that, I analyze the psychosocial conditions for the tolerance of the Other, sustaining that a failure in the symbolic intermediation is an important issue in the contemporary forms of intolerance. From that failure, the relation with ideas and persons remains on an imaginary level, and the reflection ability in inhibited, as it is in a fetish. My conclusion is that a symbolic intermediation between the Ego and the other is a condition to a tolerant coexistence.

Keywords: intolerance; psychoanalysis; contemporaneity.

\section{Introdução}

Os pavios andam especialmente curtos de alguns anos para cá. A simples menção a um termo que possa vir a ser interpretado de forma ofensiva por alguém, ainda que sem esta intenção no contexto em que foi usado, gera uma reação forte de recusa. Esta defesa é feita, aliás, sob o argumento da empatia com relação a cada um que possa se sentir ofendido. Ironicamente, a busca por empatia pode fazer a intolerância à expressão do outro voltar pela porta dos fundos.

Nas redes sociais, muitas pessoas ainda caçam qualquer coisa que possa ser posta em evidência para atacar o "outro lado" e expressam seu gozo ao conseguir fazê-lo. Já a expressão e as publicações do "outro lado" são sempre consideradas ofensivas e irracionais, gerando furor e desejo de aniquilamento. O policiamento raivoso imposto ao outro não tem a contr apartida da autocrítica, no entanto. A agressividade e ofensa que partem da própria pessoa dificilmente é percebida ou, no máximo, é justificada numa narrativa de defesa. Aquele que 
se sente violentado pelo outro se considera liberado para exercer sua própria violência. Parece bastante claro que tais atitudes reativas mútuas só podem levar a uma escalada de intolerância e ódio.

A intolerância acompanha as relações humanas. Ao mesmo tempo, podese perceber que há momentos ou contextos culturais nos quais ela parece maior ou menor. Por alguns motivos, que exporei adiante, considero que vivemos um momento especialmente recrudescido de intolerância.

Neste artigo, meu objetivo é explorar algumas hipóteses psicanalíticas para a compreensão de algumas formas da intolerância, especificamente aquelas que tomam em nosso ambiente contemporâneo. Meu objetivo é operar uma reflexão psicanalítica alinhada em três ideias-chave: (a) parto de uma concepção sobre a relação entre a intolerância e a formação do $E u$ : em sua formação, ele se afirma na diferença com relação a um outro, vivido inicialmente como hostil; (b) abordo também a mobilidade das fronteiras estabelecidas entre o Eu e o não Eu; (c) a partir desta dinâmica predominantemente individual, passo a uma análise das condições psicossociais para a tolerância ao outro: é na instituição de uma intermediação simbólica entre o Eu e o Outro que pode haver uma condição de convivência mais tolerante. Procuro aplicar os desenvolvimentos iniciais numa reflexão sobre dois fenômenos: a Operação Lava Jato e um artigo de Ana Paula Cortat, chamado "Antes, podia". Analiso, brevemente, por fim, um livro recente de Amós Oz, Como curar um fanático.

\section{A intolerância e as fronteiras do Eu}

'Tolerar' significa aceitar, suportar. Seu negativo - a intolerância- é psicologicamente uma reação defensiva do Eu. Uma afirmação da própria identidade e expulsão do que pareça ameaçador a ela. É uma prevenção ante a iminência de um trauma (SANTI, 2005). Trata- se de uma sensibilidade alérgica.

Pode-se imaginar, então, que a intolerância é própria de um Eu forte; mas, não. Um Eu forte é, para a psicanálise, aquele que se faz flexível e busca por soluções de compromisso entre as forças em ação; ele se deixa afetar e transformar e se permite cair e se perder, pois confia que poderá se recompor: "E para o Eu será possível evitar a ruptura em qualquer direção, ao deformar a si mesmo, permitir danos à sua unidade, eventualmente até se dividir ou partir" (FREUD, [1924], 2011, p. 182).

Em sua rigidez, o Eu intolerante denúncia seu terror à dissolução: sua insegurança. Assumimos a hipótese, desde esta perspectiva, de que a intolerância pode ser a marca de uma identidade ainda em construção 
(situação pela qual todos passamos), precisando se assegurar e reassegurar a cada instante; ou, ainda, a marca de um Eu traumatizado, que experimentou excessos que puseram em risco sua integridade.

Mesmo por este caminho, que busca certa empatia na compreensão da intolerância, dificilmente alguém intolerante atrai simpatia, uma vez que aquele Eu reativo busca se impor sobre o outro, a quem procura desqualificar (ou mesmo aniquilar). A intolerância tende à violência e ao isolamento da pessoa em si ou em seu grupo identitário.

A condição humana faz de nós seres relacionais, de misturas, conflitos e compromissos: a intolerância gostaria de se abster desta confusão e "sujeirada" humana. O que é nossa origem num ato sexual senão a arte da mistura? Mas a intolerância busca ser asséptica e ascética: pura e acima do mundano. É como no sonho irrealizável de Narciso: não depender de ninguém, não ter ninguém dependendo de si.

Não nascemos tendo de início um Eu (FREUD [1931], 2010), Ele será precipitado pela percepção, por parte da criança, de que há vazios, espaços e descontinuidades entre a própria experiência e a daqueles de quem vêm o cuidado e afeto básicos. Em termos teóricos, a desfusão com a figura materna (quem quer que exerça a função). Só há um Eu quando há um não-Eu, um Outro. Os 'nãos' emitidos pelo outro e pelo Eu demarcam as fronteiras onde um acaba e outro começa. É difícil dizer não a quem amamos ou de quem dependemos, pois ao fazê-lo damos prova de descontinuidade e de frustrar as fantasias de fusão e identidade. Temos, então, medo do abandono ou do ataque do outro.

A criança humana provavelmente vive mergulhada em experiências e sensações intensas de prazer e desprazer. Naturalmente, o Eu busca reter tudo que lhe dê prazer e segurança; e repudia e busca evitar tudo o que for mau. Numa formulação clássica de Freud, o Eu incialmente se identifica com o bom e projeta o mau: Eu é bom, não-Eu é mau.

Assim, a vida humana é dependente e ancorada num outro desde sua origem e como sua condição, mas sua primeira representação do outro tende a ser a de um inimigo que frustra e ataca: a fonte de todos os males. Para outra psicanalista, Melanie Klein, a experiência infantil mais primitiva não conhece o vazio: sua experiência seria uma "aquisição" que requer certa maturidade: “(...) nos primeiros meses de vida, a ansiedade é predominantemente vivenciada como um medo de perseguição" (KLEIN, 1991, v. 3, p. 41). De início, ora a criança vê um outro bom (mãe boa, seio bom), fonte de todas as satisfações; ora, em momentos de frustração e dor, vê um ser mau. O mundo infantil é sempre animado (no sentido de preenchido por presenças) e quando 
a luz do quarto se apaga na hora de dormir, ele não fica vazio: cessado o "input" de estímulos ambientais, a consciência é invadida por fantasias, em grande parte, destrutivas e persecutórias

Ao longo de seu desenvolvimento/amadurecimento, o Eu em geral vai se dando conta de que aquela cisão entre o absolutamente bom e o mau não existe; ele passa a poder integrar parcialmente seus aspectos mais destrutivos (negativos) e reconhecer valor no outro. A mesma mãe que vem e atende é a mãe que vai ou demora a vir. Aqui surge a experiência do vazio: nem tudo de mal ou bom que acontece tem um "sujeito". Mas esta aquisição é sempre incompleta e sujeita a regressões em situações de força emocional (quando se mexe com nossa família, time de futebol, posições políticas...). O Outro vivido como mau, inimigo ou concorrente poderá ser visto também como amoroso, parceiro, acolhedor. O fim das idealizações que fazemos sobre nós é também o fim da idealização do Outro: nem um nem outro absolutamente bom ou mal, onipotente ou impotente.

Voltando à Klein, nesta condição, a criança passa a se sentir culpada. Ela se dá conta que aquele ser frustrante e violento que odiou é o mesmo a quem ama e que lhe dá amor. O Outro é visto agora não como parte (boa ou má), mas como um ser total. Da culpa sentida pelos ataques desferidos, pode nascer o desejo de reparar os estragos produzidos e, adiante, o sentimento de gratidão por aquele ser. Reparação e sentimento de gratidão: temos aqui uma das versões para a origem da condição de empatia pelo outro: se eu sofro ante o ataque, o outro também deve sofrer ante meus ataques (KLEIN, 1996).

Como premissa do processo de identificação, somos capazes de sentir apenas nossos próprios sentimentos e, quando crianças, vemos o outro apenas como objeto de seus interesses ou instrumento para alcançar seus fins. É também uma aquisição do amadurecimento conceber que o outro também tem uma consciência e pode sofrer; não somos "um" com ele; ele não existe para nos satisfazer. Ele é, de fato, outro ser. É preciso aprender isto: compreender que o outro também sente como eu não é uma experiência imediata.

Vale dizer que o limite de nossa empatia ou relação para com o outro tem este limite, ainda de ordem narcísica. Só conseguimos ter empatia ou compaixão (dois termos derivados de 'pathos', como compartilhamento dos mesmos sentimentos) se conseguimos nos ver na situação em que o outro se encontra (se fosse comigo...). O outro que não nos concerne e que passa por algo que não concebemos que possa se dar conosco não nos comove. Em suma, haveria uma relação direta entre a necessidade de autoafirmação (e só necessita quem não tem) e a intolerância ao outro. 


\section{As fronteiras cambiantes do tolerável}

Nesta segunda parte do texto, a questão da intolerância de uma perspectiva psicanalítica permite refletir sobre a mobilidade contínua das fronteiras entre o que é ou não tolerável. A divisão $E u / n a ̃ o-E u$, tal como vimos na primeira parte, não é clara ou definitiva e sofre transformações constantes.

Uma situação relatada em meu consultório será o ponto de partida. Um homem na faixa de seus 20 anos recentemente se tornou vegetariano. Naturalmente, ele enfrenta alguns desafios novos em sua vida social: em alguns ambientes é difícil encontrar opções que atendam ao seu vegetarianismo. Esta dificuldade o perturba cada vez mais, a ponto de fazê-lo deixar alguns lugares, ofendido. De um lado, ele entende que tem o direito de escolher ser vegetariano e que os demais têm o direito de fazer suas opções de hábito alimentar; de outro, ele passou a considerar verdadeiramente errado comer carne e passa a se irritar com quem o faz. Agora, ele passa a ter ímpetos de discutir com todos para convencê-los a mudar de hábito. Neste caso, o outro estaria alienado de uma realidade cruel e seria algo fundamentalmente bom corrigi-lo de um mau hábito. Ainda refletindo, diz que não chega ao ponto de ser vegano, pois come ovos e queijo. Ou seja, ele considera que também não faz o que é certo até o extremo, embora esteja tentando melhorar.

O paciente está em momento de passagem e reacomodação em seus valores; em período de viva reflexão, sofre com os ajustes, atritos e "traduções" que deve fazer de seus valores anteriores. Certas ideias que incorporavam seu $E u$ como naturais passam a ser vistas como vergonhosas, constrangedoras. Algumas delas não terão mais direito de cidadania e, afinal, serão reprimidas. Ele está às voltas com sua identidade e com mudanças em suas próprias fronteiras. Ao fazê-lo, evidencia que temos fronteiras que nos dão limite e diferenciam dos outros, mas também de que as fronteiras são convenções e não substâncias imutáveis.

O limite Eu/não-Eu não é simples ou estável. É dentro de um jogo de forças complexo que fronteiras se estabelecem e acomodam; mas esta acomodação tende a ser provisória e sempre sujeita a reacomodações, conforme as forças envolvidas também se transformam. Identidades são a crença na permanência de algo idêntico a si mesmo ao longo do tempo. Esta crença tende a ser ilusória, ao ignorar o cabo de guerra múltiplo dentro qual constantemente estamos. As tentativas de se manter apegado a identidades que já não dão conta das demandas atuais geram o sofrimento neurótico ("apesar de mim, estou mudando"; assim uma paciente se apresentou há alguns anos); ou, até no limite, levam a um estado delirante (que tem uma referência emblemática do filme clássico O crepúsculo dos deuses (SUNSET BOULEVARD, 1950). 
Nossa segunda hipótese é a de que o próprio $E u$ seria assim uma espécie de partido de centro, procurando encontrar soluções de compromisso entre as forças envolvidas. Uma colcha de retalhos com contradições e incoerências internas, numa dada configuração de fronteiras. Esta unidade instável cria ainda um campo de exclusão - o reprimido - que cobra seu preço e acaba por vazar de alguma forma. O que está para lá das fronteiras não deixa de ser real, passa a ficar fora do controle do $E u$ e acaba por vazar, de forma disruptiva. Além disso, tudo o que vier de encontro ao $E u$ e remeter associativamente ao reprimido provocará uma forte reação de repulsa.

Encarar o próprio desejo reprimido estampado no outro é algo fortemente ameaçador. Para a psicanálise, a sensação de nojo atesta exatamente isto: o contato com um objeto que gera uma forte excitação, mobiliza um desejo; sendo este objeto inaceitável ao conjunto representativo que constitui o $E u$ naquele dado momento, a excitação terá seu sinal trocado de atração para aversão. Algo que não tocasse algo muito profundo em nós causaria indiferença, não aversão. Na medida em que aquilo que é aceitável pessoal ou socialmente se transforma, há uma tradução: coisas aceitáveis num dado momento podem passar a ser repudiantes em outro; e vice-versa.

Dentre certas definições do que é tolerável ou não, hoje, aqueles que são mais velhos com frequência podem dizer a expressão: "antes, podia”. Ao longo do tempo, piadas ou preconceitos arraigados socialmente, ao ponto de terem se tornado invisíveis, tornam-se agora inaceitáveis. Isto não se dá necessariamente num sentido de ampliação ou progresso, mas no sentido de criar novos espaços de possibilidade do que seja aceitável, em detrimento de outros. Os vetores do jogo de forças sociais podem gerar um campo relativamente estável, mas que vai sendo repuxado pela variação das forças que sobre ele atuam.

Embora haja um discurso muito difundido pela aceitação progressiva da diversidade de comportamentos, etnias e gêneros, não estamos vivendo de fato uma simples ampliação de possibilidades e espaços, mas sim um redirecionamento, com a criação de novos campos de inclusão e exclusão. Pessoas que viam suas opções oprimidas por uma ordem vigente anterior não querem simplesmente ter direito a voz, mas o direito de tolher as vozes que lhes oprimiam. O cobertor é curto para cobrir uma área, outra fica descoberta.

E é óbvio que aqueles que tinham espaço e voz veem seu território invadido e reagem em protesto, buscando retomar a posição anterior. Este é o protesto embutido no Antes, podia. Ana Paula Cortat (2015) publicou um artigo com este nome na revista Meio \& Mensagem. O artigo foi muito difundido no meio e problematiza a linguagem arcaica e inaceitável que 
permanece corrente na publicidade, quando muitos setores da sociedade se transformaram. Eis sua conclusão:

\begin{abstract}
Ainda estamos olhando para o que fazemos acreditando que não deixamos resíduos na sociedade. Será que precisamos de leis que nos digam que não podemos sexualizar crianças? Estimular a violência contra mulheres? Estimular ou legitimar qualquer tipo de fobia? Ainda usamos o acaso, a ignorância, a não intencionalidade para justificar nossa falta de contato com a realidade e nossa falta de consciência. Não dá mais. Chega. Definitivamente, isso não pode. (CORTAT, 2015)
\end{abstract}

Importantes transformações culturais trouxeram o imperativo de preservar identidades e não submetê-las a formas de opressão que nos pareciam, pelo poder do hábito, naturais. O século XXI tem sido o cenário de lutas acirradas por parte de grupos identitários que, a cada movimento seu, afetam outros grupos que se veem ofendidos ou invadidos e reagem proporcionalmente a seu sentimento, retroalimentando a invasão e gerando ódio. Isto se dá pelo simples fato de cada entidade existir e ocupar espaço, mesmo que não haja uma intenção provocativa; o que por vezes também acontece, é claro. Nossa simples existência já nos coloca em posição de afetar o outro; e vice-versa. Não há dúvida de que haja algo de positivo nestas afirmações de si e na recusa por aceitar opressão, mas passamos a pagar o preço do atrito gerado por isto.

Para que não corrêssemos o risco de ofender ninguém, por outro lado, precisaríamos nos anular ou nos fechar. Este é o problema daquela meta politicamente correta de procurar prevenir que uma expressão possa vir a ofender alguém. Como ninguém está disposto a se aniquilar, grupos cada vez mais fechados se formam, evitando expor os conflitos, procurando se "purificar" e não se misturar. Esta direção gera feudos e mônadas e não uma comunidade mais plural: um aglomerado de individualidades avessas umas às outras. Isto não é convívio com a diversidade: é a vitória da intolerância.

\title{
A tolerância mútua depende de mediação social
}

Vimos até aqui, em termos básicos, como as origens da tolerância possuem relação com a própria constituição do $E u$, assim como com as mudanças que as fronteiras entre o $E u$ e o $n \tilde{o} o-E u$ sofrem. Passemos agora a estender a questão para uma dinâmica de relação grupal, desde uma perspectiva psicanalítica.

Ao longo da vida, a dinâmica inicial da formação da mente com a cisão $E u$ / bom-Outro/mau se replica na formação dos grupos familiares e de pertinência. A convivência em grupos onde encontramos acolhimento, proteção ou 
amizade gera atritos normais. É difícil lidar com a ambivalência afetiva: amamos e odiamos ao mesmo tempo as mesmas pessoas. E o mecanismo para preservar aqueles que amamos de nosso ódio é, uma vez mais, a projeção da agressividade em outros grupos. Estar em grupo e falar mal de outros grupos é um forte componente de coesão. Criamos intimidade, cumplicidade, afirmamo-nos como superiores e conseguimos "queimar" nossa hostilidade interna voltando-a para fora.

Assim, cada entidade identitária (pessoa, família, tribo, grupo de trabalho, esporte, religioso, etc) afirma-se ante e anti um outro grupo, depósito projetivo de todos os males. Nossas imperfeições e insuficiências, a frustração com o mundo que não se dobra aos nossos desejos, tudo é atribuído à ação incompetente ou malévola do grupo adversário. Damos forma antropomórfica ao vazio e ao infortúnio.

Freud forjou o expressão 'narcisismo das pequenas diferenças' para descrever como elegemos nossos inimigos privilegiados. Eles são escolhidos por identificação: alguém de nosso tamanho e parecidíssimo conosco:

\footnotetext{
Certa vez discuti o fenômeno de justamente comunidades vizinhas, e também próximas em outros aspectos, andarem às turras e zombarem uma da outra, como os espanhóis e os portugueses, os alemães do norte e os do sul, os ingleses e os escoceses etc. Dei a isto o nome de 'narcisismo das pequenas diferenças'. (FREUD, 2010, v. 18, p. 81).
}

Não nos afirmamos ante a alguém muito maior ou menor do que nós mesmos, mas ante a semelhantes. Atacamos no outro o que não suportamos em nós, como na velha e boa piada sobre o homofóbico ser alguém "no armário". Mas esta é a dinâmica de quem conseguiu ser incluído no grupo que almejava. O que ocorre com quem não conseguiu? A experiência da exclusão é arrasadora e gera um sentimento de diminuição, não merecimento, desamor. Costuma se seguir a isto o isolamento ou o encontro com outras pessoas na mesma condição, e elas formam um novo grupo, o grupo dos excluídos. Um grupo formado assim por pessoas cheias de ressentimento por terem sofrido exclusão costuma ser ainda mais coeso. Sentindo-se potentes em grupo, eles costumam reproduzir a violência que sofreram e ser especialmente intolerantes.

Voltando à convivência em grupo, ela presume uma intermediação entre os indivíduos que o compõem. Esta intermediação é dada pelo compartilhamento por parte de seus membros da idealização de um ideal. Pode ser uma ideia ou figura de liderança. Mas é através de uma intermediação simbólica que cada indivíduo ultrapassa sua luta primária por interesse e passa a se sentir fortalecido pela pertinência a um grupo. Cada um projeta na figura de 
referência os ideais aos quais renunciou no processo de amadurecimento. Meu líder encarna meu Eu ideal: onipotente e perfeito como um dia se acreditou ser, até a realidade se impor e criar uma noção de nossos alcances e limites (FREUD, 2011, v.15, p. 91).

Os membros do grupo se irmanam justamente por compartilharem a idealização ao mesmo objeto. Este é o caminho do convívio social e das negociações, em medida motivadas pelo medo do abandono e da solidão São os pactos sociais descritos por Freud e Hobbes (ENRIQUEZ, 1990) por exemplo. Para ambos, aliás, a primeira motivação para o convívio social é o medo de morrer. A consciência de nossos limites e o destino inevitavelmente mortal da pura luta por nos impormos em busca de poder e prazer. Para a psicanálise, isto é instituído pela função paterna, no complexo de Édipo. A criação do laço simbólico é correlata ao fim da idealização de si e do outro, com o nascimento do vazio e condição de relação real com o outro.

É por este caminho que nos descolamos dos processos primários de busca por prazer e entramos no caminho da experiência política. Renúncia ao prazer imediato, inclusão no laço social, garantias básicas de proteção por parte do grupo, caminhos disponíveis para prazeres possíveis. O processo é frustrante para quem se acreditava onipotente; além disso, deixa restos reprimidos e paga-se o preço por eles sob a forma de neurose.

Naturalmente, para que este processo se consuma, é necessário que a posição simbólica se instaure com autoridade e justiça: todos devem ser iguais perante a lei para que o pacto funcione para indivíduos que, a princípio, querem tudo para si. Os indivíduos todos devem ser iguais entre si, mas todos querem ser dominados por um só. Muitos iguais, que podem identificar-se uns com os outros, e um único, superior a todos eles - "esta é a situação que se acha realizada numa massa capaz de subsistir" (FREUD, 2011, p. 83).

De uma situação primitiva de domínio por um ser mais forte, passouse à instituição da instância simbólica que intermedia as relações entre os membros do grupo. A autoridade provém da condição de que ela se mostre justa e impessoal e cada um possa confiar nela. Quando a autoridade falha, quem ocupa o lugar de poder muitas vezes apela para o autoritarismo, ou seja, para a forca. A autoridade se ancora no simbólico, o autoritarismo no imaginário e no real.

Assim, o acesso à dimensão simbólica proporciona um distanciamento relativo da experiência imediata, o que produz um efeito ambivalente: de um lado "perdemos o paraíso" da crença em certezas e onipotência; de outro, ficamos a salvo da onipresença persecutória de um outro maléfico. Sofremos com a falta, mas nela desfrutamos do privilégio da solidão. 
Nossa terceira hipótese se apresenta aqui: caso haja, no exercício da força, característico da função paterna, a suspeita de que ela não esteja agindo de acordo com o que é justo e válido para todos, aquela força será vivida como pura violência e exercício de gozo sádico. Aquele que a sofre não irá renunciar ao seu prazer imediato em função de um pacto simbólico, mas estará sob uma situação de terror. A figura paterna sem autoridade simbólica e agindo de acordo seu interesse não irá operar uma castração simbólica, mas sim uma mutilação real; não exercerá a função paterna, mas a de mãe má persecutória (SANTI, 2004).

Penso que esta tensão pode ser acompanhada na Operação Lava Jato e na figura do juiz Moro: do que se trata? De uma tentativa inédita de rever a cultura de corrupção arraigada do país ou de uma perseguição arbitrária a um grupo específico? Trata-se de arbítrio jurídico ou de uma arbitrariedade policial ? Autoridade ou autoritarismo? Estamos procurando a construção de um novo pacto social ou nos vingando do Partido dos Trabalhadores, que ousou chegar ao poder? Mesmo que se trate do primeiro caso, aqueles que são acusados e não veem autoridade no processo procurarão desqualificá-lo e atacá-lo, procurando fazer com que pareça o segundo caso (perseguição, como na expressão recorrente: "vazamento seletivo de informações do processo"). Penso que há uma séria crise de autoridade simbólica; inclusive porque é um negócio seguro buscar defeitos e falhas morais nos outros. Como instaurar um termo simbólico compartilhado?

Quando, no fim dos anos 1970, o antropólogo norte-americano Christopher Lasch (1982) forjou a expressão 'cultura do narcisismo', muita gente imaginou que se tratasse de uma referência à nossa vaidade e individualismo. Mas, para a psicanálise, há muito mais implicado nisso: justamente numa falha do processo edípico numa dimensão social e na permanência de um modo mais primitivo de experiência.

Como nova hipótese, aqui se encontram os dois processos: de um lado, o individual de passagem do narcisismo (renúncia às fantasias de onipotência) e entrada no mundo da falta e do desejo; de outro, o processo social de ultrapassagem de um estado de individualismo bruto para um pacto social, mediado por uma instância simbólica (FREUD [1930], 2010, p. 62).

Operado o complexo de Édipo, entramos no mundo da cultura e dos prazeres possíveis: passamos a sofrer com o sentido de falta e insatisfação, mas adquirimos o benefício da capacidade de estarmos sós. Onde não se instale a falta, operada pelo que chamamos de castração simbólica, ficamos entregue a um excesso de presença, com idealizações de figuras acima de qualquer possibilidade de falha ou crítica e à mercê de inimigos odiosos a nos perseguir. 
Socialmente, vivemos uma forte crise nesta instauração do simbólico. Ante a falta de confiança numa instância simbólica, qualquer um que procure se afirmar como autoridade a demandar por renúncia às nossas idealizações será percebido como um ser autoritário e agressivo. Esta presença será vivida como algo que quer cortar meu prazer, suspeitar de minhas referências, ferir meu narcisismo; mas só o meu, não o de meus adversários. Com a dificuldade de que alguém ocupe uma posição de distanciamento e intermediação simbólica reconhecida por parte significativa da sociedade, as figuras de autoridade são vividas como "autoritárias", perseguidoras.

Neste artigo, tenho procurado sustentar a ideia de que a capacidade de tolerância entre as pessoas depende de uma intermediação simbólica social. Sua ausência entrega cada um a um sentido de desproteção, defesa e persecutoriedade. A desautorização das instâncias simbólicas parece ser uma receita segura para a formação de milícias coesas, fanáticas e, portanto, violentas. Com a corrosão destas e demais figuras de autoridade, parece restar um "cada um por si". E fanáticos de lado a lado se aglutinam em tom de guerra, e planejam suas manifestações. Militantes a militar ganham novo ânimo.

Voltemos à reflexão sobre a crise das intermediações simbólicas no exemplo da Operação Lava Jato e ao questionamento sobre suas motivações e legitimidade. A cena da condução coercitiva do ex-presidente Lula por algumas horas para depor, em março de 2016, parece ter se tornado um fetiche coletivo, catalizador de militantes pró e contra ele. Houve uma grande excitação em torno desta cena aguardada/temida, talvez, desde o "Mensalão", há dez anos.

Por que chamo a relação com esta cena de 'fetiche'? O termo deriva de feitiço, encantamento, algo em que se fica fixado irresistivelmente. Em psicanálise, fetichismo descreve uma condição erótica condicionada pelo reencontro com uma cena extremamente específica. A excitação extrema ligada à cena cria um caráter compulsivo (FREUD, 2014) Freud ampliou o conhecimento do fetichismo teorizando como o objeto de fetiche é escolhido e a que serve a fixação a ele. O objeto do fetiche seria escolhido por contiguidade ao encontro terrível com a falta (o que chamamos de castração simbólica). Em português, isto quer dizer que a cena do fetiche seria a última coisa vista logo antes da percepção do horror da incompletude. E é exatamente para evitar seus efeitos que nos deteríamos na imagem anterior. O fetiche procura ser a recusa do real que se impõe à nossa onipotência.

Voltemos à cena de "Lula preso". Para seus opositores, a fixação nesta cena permite que ignorem que "o buraco é mais embaixo" e que ele está longe de ser o "núcleo duro da corrupção". Nossa corrupção se espalha pela história brasileira e pelo nosso cotidiano, nas pequenas e grandes vantagens que buscamos obter (sim, em primeira pessoa). O que haveria para depois da 
queda de Lula e do PT? A crise econômica e de governabilidade são muito anteriores e posteriores, como ora vemos.

Para aqueles que têm Lula como um líder, a notícia de sua prisão fez com que todo o contexto de revelação dos descaminhos do poder fosse esquecido. Mesmo aqueles capazes de autocrítica até a véspera tiveram sua reflexão zerada pela cena da prisão. É quase como se tivesse havido um alívio: a alegada arbitrariedade da prisão temporária teria restituído Lula e o PT a seu contexto de origem, em luta contra o regime militar. As denúncias de que teríamos estado num Estado de Exceção, em pleno governo Dilma, negava o simples fato de que o PT ocupava o poder federal há 13 anos. De réu, Lula passou a mártir.

Centrar as atenções no "nós contra eles" nos ajuda a todos a mantermos afastada uma realidade bem mais dura e difícil. Seduzidos pelo fetiche, nem começamos a pensar. Da mesma maneira, em estado de guerra e na urgência em se garantir a própria sobrevivência, não é possível pensar, fazer autocrítica ou qualquer coisa do gênero. Talvez haja até uma conivência coletiva em se manter o estado de urgência. Todos ficam poupados do doloroso exercício de refletir sobre si e as próprias formas com que estamos implicados nas situações de crise.

No campo político, os grupos partidários majoritários hoje no Brasil (que tanto se comprazem em apontar a corrupção um do outro e são incapazes de uma autocrítica, atribuindo qualquer acusação a eles como "motivação política"), há trinta anos viviam sob o pacto da Nova República, contra inimigos em comum. Paradoxalmente, com a vitória daquela causa, passaram a se digladiar intolerantemente pelo poder. $\mathrm{O}$ resultado, foi o esgarçamento daquele pacto simbólico, o que, tudo indica, contribuiu para nosso regime de guerra e intolerância.

Tudo leva a crer que só ante um novo medo ou ideal em comum e reconstituição de um pacto simbólico poderíamos sair do impasse em que nos encontramos. Isto independente dos atores do pacto social anterior que, aparentemente, perderam em boa medida a representatividade popular. A tolerância mútua também é constituída pela mediação simbólica social.

\section{“Como curar um fanático": notas finais}

Nesta parte final do texto, vale uma menção ao livro de Amós $\mathrm{Oz}-$ Como curar um fanático, lançado ao final de 2015, no qual o autor estabelece algumas ideias que dialogam fortemente com os desenvolvimentos anteriores sobre a questão da intolerância: aqui se encontram a questão da cisão $E$ u/não-Eu, a ameaça representada pelo Outro, a tensão das fronteiras e a necessidade de 
estabelecimento de intermediações simbólicas. A adesão do fanático a ideias e valores que lhe são sagrados tornam-no um intolerante em potencial.

Segundo Oz (2015) hoje, o embate mais importante não se dá entre esquerda/direita, machismo/feminismo, Israel/Palestina ou qualquer outra polaridade de identidade cultural ou ideológica. $\mathrm{O}$ embate crucial é contra os fanáticos, existentes transversalmente em qualquer grupo identitário. É a certeza absoluta do fanatismo que o leva à arrogância de buscar "salvar", "educar" ou, caso falhe na missão, aniquilar quem não compartilhe de seus valores. Da mesma forma, qualquer um que aponte críticas à posição do fanático é visto como um inimigo que o quer destruir, o que o torna objeto legítimo de ódio. Se eu tenho certeza, quem pensa diferentemente de mim não é apenas diferente, mas errado.

Pode soar como 'relativismo' a opção por abstrair o mérito intrínseco de cada lado de um conflito. Mas não se trata de pregar o 'relativo', e sim de focar a atenção nas formas de 'relação' com o Outro. A questão, portanto, não está colocada no que é ou não tolerável, mas em analisar como nos relacionamos com quem se apresente como "Outro".

O fanatismo não permite acordo ou compromisso: como ele só repousaria na eliminação da diferença, o que é improvável, ele impõe um interminável e infrutífero "nós contra eles". Há formas de relação com o outro que se baseiam em alguma capacidade de autocrítica e capacidade de compreender a posição do outro (empatia). Com esta premissa, Oz trata da delicadíssima relação entre Israel e Palestina: como israelense, ele é capaz de conceber que o conflito não se dá entre um lado certo e um errado, mas entre um certo e outro certo, desde a perspectiva de cada um. Isto não o torna menos israelense e defensor de suas posições.

O tema das palestras de Amós $\mathrm{Oz}$ me parece o mais atual e necessário possível, quando tantos grupos buscam, em sua válida autoafirmação, calar aqueles por quem se sentem oprimidos. Sofrer ou ter sofrido a opressão parece fornecer uma "cota" de revide violento, o que simplesmente inverte a direção da violência, realimentando-a. Pregar a liberdade de expressão ou a aceitação da diversidade não pode se reduzir a pleitear a aceitação da própria expressão, mas sim estar disposto a brigar pela expressão de pessoas e ideias com as quais não me identifico e, mesmo, discordo.

Os remédios propostos pelo livro parecem singelos, mas vão à raiz da questão: curiosidade e humor. Fanáticos não possuem um ou outro, assentados que estão sobre sua verdade e causa messiânica de salvar o mundo, que funciona como fetiche, como já vimos. Trata-se da instauração de uma mediação simbólica. A curiosidade já implica uma atitude de abertura e interesse pelo novo e pela diferença, na consciência de que aquilo que é sabido não é tudo. 
E o humor implica um distanciamento do imediato, a capacidade de não se levar plenamente a sério, a capacidade de reflexão (sobretudo naquele tipo de humor no qual rimos de nós mesmos). E é com uma boa dose de humor irônico que $\mathrm{Oz}$ diz que o fanático é o verdadeiro altruísta: ele pensa mais nos outros do que em si.

Contra o fanatismo, o caminho parece ser a busca por mediações e compromissos, o que implica renúncias. Oz toma o caminho de Freud em suas concepções sobre nossos conflitos psíquicos e como lidamos com eles. Ante o sofrimento e a frustração, qualquer um pode ter o impulso de aniquilar aquele que lhe pareça o responsável por nossos limites. Ambos os autores sabem que, afinal, a alteridade não pode e não deve ser aniquilada. Mesmo o eventual desaparecimento do outro não restituiria a onipotência fantasiada originalmente pelo $E u$. Para $\mathrm{Oz}$ e Freud, viver dói e é na companhia dos demais humanos igualmente frustrados e em conflito que conseguimos criar uma condição para suportar e desfrutar a vida. Alguma meta consistente em comum pode nos irmanar.

Em conclusão ao trabalho de $\mathrm{Oz}$, restou uma dúvida irônica: pela própria definição de Amós $\mathrm{Oz}$, o projeto de curar um fanático não teria então ele mesmo uma inspiração...fanática?

A intolerância é uma forma de desaguar nossa agressividade e frustração; é também uma forma de nos apegarmos a ideais frente à realidade que não cede ao nosso desejo e nos informa, a todo instante, que há um outro em nós. Um outro que repudiamos e expulsamos sobre os outros a quem, por isto, sentimo-nos autorizados e liberados para atacar. E isto se torna mais agudo quando não acreditamos contar com alguma instância de justiça ou mediação para regular as relações.

Procuramos desenvolver uma linha argumentativa na qual se parte da intolerância como defesa de um $E u$ em formação ou acuado, em busca de uma delimitação entre o Eu e o Outro; neste movimento de fronteiras movediças, projetamos sobre o outro tudo o que há de mal para que possamos nos identificar com o que seja bom. Chegamos a uma dimensão propriamente política na qual trabalhamos a ideia de que é imprescindível uma mediação simbólica entre o Eu e o Outro, um distanciamento relativo que nos preserve da experiência primitiva de estarmos sendo atacados pelo outro. Assim, surgem as noções de justiça, empatia e humor como antídotos à intolerância.

Quando pensamos em intolerância, pensamos na intolerância dos outros, naquela que sofremos. Ancorados em nossa onipotência infantil imperfeitamente superada, reclamamos ser tolerados, termos mais espaço e voz. Nesta dimensão, não nos percebemos no próprio jogo do poder, ao 
ocupar espaços e constranger o outro. Só nos damos conta da violência deste jogo quando sofremos a invasão ou perda de lugar debitada a um outro.

Uma reflexão só merece este nome se formos capazes de nos incluir nela, e não apenas falarmos com distanciamento, supostamente objetivo, das fraquezas dos outros. O grande desafio mental é identificarmos nossos próprios pontos cegos e sagrados: a intolerância que exercermos.

$\mathrm{O}$ que temos adiante é a necessidade de seguirmos nos confrontando e estudando questões relativas à identidade e à alteridade em nosso ambiente contemporâneo, às modalidades que a vida política assumirá, às composições que os conflitos e jogos de força assumirão. Nosso trabalho de reflexão é vivo e combate os fanatismos quando retorna às nossas relações humanas e as transformam.

\section{Referências}

CORTAT, A. P. Antes, podia. Meio \& mensagem. Disponível em: https://grupodeplanejamento. com/2015/11/06/artigo-antes-podia-por-ana-cortat/ Acesso em março de 2016.

ENRIQUEZ, E. Da horda ao Estado. Rio de Janeiro: Zahar, 1990. 404 p.

FREUD, S. O mal-estar na civilização (1930). In: Edição standard brasileira das obras psicológicas completas de Sigmund Freud, v. 18. Tradução Paulo Cesar de Souza. São Paulo: Companhia das Letras, 2010, p. 13-12.

FREUD, S. Psicologia de massas e análise do eu (1921). In: Edição standard brasileira das obras psicológicas completas de Sigmund Freud, v. 15 (1920-1923). Tradução Paulo Cesar de Souza. São Paulo: Companhia das Letras, 2011, p. 91.

FREUD, S. Neurose e psicose (1924). In: Edição standard brasileira das obras psicológicas completas de Sigmund Freud, v. 16 (1923-1925) Tradução Paulo Cesar de Souza. São Paulo: Companhia das Letras, 2011, p. 176-183.

FREUD, S. O fetichismo (1927). In: Edição standard brasileira das obras psicológicas completas de Sigmund Freud, v. 17 (1926-1929). Tradução Paulo Cesar de Souza. São Paulo: Companhia das Letras, 2014, p. 302-310.

KLEIN, M. Amor culpa e reparação: e outros trabalhos (1921-1945). In: Obras Completas de Melanie Klein, v. 1. Rio de Janeiro: Imago, 1996.

KLEIN, M. Notas sobre alguns mecanismos esquizóides. In: Obras Completas de Melanie Klein, v. 3. Tradução Elias Mallet da Rocha, 4. ed. Rio de Janeiro: Imago, 1991, p. 17-43.

LASCH, C. A cultura do narcisismo: a vida americana numa era de esperanças em declínio. Tradução Ernani Pavaneli. Rio de Janeiro: Imago, 1982. 
SUNSET Boulevard. Direção: Billy Wilder. Produção: Charles Brackett. Paramount Pictures (110 min.), EUA, 10 ago. 1950.

OZ, A. Como curar um fanático. São Paulo: Companhia das Letras, 2015. 104 p.

SANTI, P. L. R de. A paranóia como crise da autoridade: ou, não é só porque você é paranóico que não tem ninguém the perseguindo. Psyche, São Paulo, v. 8, n. 14, p. 123-146, dez. 2004 . Disponível em http://pepsic.bvsalud.org/scielo.php?script=sci arttext\&pid=S1415$11382004000200008 \& \operatorname{lng}=$ pt\&nrm=iso $>$. Acesso em: 12 set. 2016.

SANTI, P. L. R de. Consumo e desejo na cultura do narcisismo. Comunicação, Mídia e Consumo, São Paulo, v. 2, n. 5, p. 173-204, nov. 2005. Disponível em: <http://revistacmc. espm.br/index.php/revistacmc/article/view/52/53> Acesso em: 12 set. 2016.

Submissão em: 30/09/2016

Aceite em: 14/02/2017

Pedro Luiz Ribeiro de Santi é psicanalista, possui graduação em Psicologia pela Pontifícia Universidade Católica de São Paulo, mestrado em Filosofia pela Universidade de São Paulo e doutorado em Psicologia (Psicologia Clínica) pela Pontifícia Universidade Católica de São Paulo (2000). Atualmente é professor titular e líder da área de Humanidades e Direito da ESPM e professor da especialização em Teoria Psicanálitica da COGEAE/Pontifícia Universidade Católica de São Paulo. Tem experiência na área de Psicologia, com ênfase em Intervenção Terapêutica, atuando principalmente nos seguintes temas: psicanálise, Freud, modernidade, subjetividade, narcisismo e consumo.

Endereço: Rua Haddock Lobo, 144/111. São Paulo/SP, Brasil. CEP 01414-000. E-mail: psanti@espm.br 